\title{
Hitabet Sanatı ve Eski Yunan-Roma, Türk ve Cahiliye Dönemi Arap Hitabeti
}

\section{The Art of Rhetoric and Rhetoric in Communities of Ancient Greek-Roman, Turkish, and Arabics' Ignorance Periods}

\author{
Uzman Öğretmen Abdurrrahman BAŞCI ${ }^{1}$
}

\begin{abstract}
Özet
İnsanlık tarihi incelendiğinde hitabetin önemi ve kitleler üzerinde güçlü bir etkiye sahip olduğu aşikârdır. Çünkü hitabetin insanlar arasındaki iletişimi sağlayan yegâne bir unsur olduğu düşünüldüğünde, herhalde hitabetsiz bir toplum hayal bile edilemez. Bu çalışmanın ilk bölümünde hitabetin tanımı, konusu, amacı, önemi, belagatle ilişkisi ve bir sanat olduğuna vurgu yapılmaktadır. Ayrıca hitabetin çeşitleri şekil yönünden değil, konuları açısından ele alınmaktadır. Bu bağlamda hukuki, ilmi, askerî, siyasi, diplomatik ve dini hitabetler hakkında bilgi verilmektedir. Çalışmanın ikinci bölümünde ise eski Yunan ile Roma, Türk ve İslamiyet öncesi Cahiliye devri Arap hitabetinden bahsedilmektedir.
\end{abstract}

Anahtar Kelimeler: Hitabet, belagat, inşâd, hatip, cahiliye

Makale Türü: Derleme

\begin{abstract}
It is obvious that rhetoric has important and strong effects on community when reviewed history of humankind. The reason of this, rhetoric is the only element which make connection between people. It cannot be imagined that a society without rhetoric. In the first part of this study is addressed the definition, subject, aim, importance, art of rhetoric, and its relationship with oratory. In addition, the types of rhetoric is addressed about their subjects not of form. In this context, it is referred related to legal, scientific, military, political, diplomatic and religious rhetoric. In the second part of this study, it is mentioned rhetoric in Ancient-Greek, Roman, Turkish, and Pre-Islamic Ignorance periods.
\end{abstract}

Keywords: Rhetoric, oratory, recitation, rhetorician, ignorance

Paper Type: Review

${ }^{1}$ Eskişehir Osmangazi Üniversitesi, Temel İslam Bilimleri Anabilim Dall, abdbsc@hotmail.com, Orcid ID:
https://orcid.org/0000-0003-2964-5761 


\section{Giriş}

Hitabetin doğuşu, insanoğlunun yaratılış tarihine kadar uzanmaktadır. Çünkü Allah (c.c.), ilk insan Hz. Âdem'i (a.s.) peygamber olarak seçmiş, yakın çevresine ve ailesine dine ve ahlaka ait hususları tebliğ etmek üzere görevlendirmişti. Hz. Âdem (a.s.)'in bu emri yerine getirirken uyguladığı yöntem, hitabettir. İlk peygamber ile başlayıp devam eden "hitabetin insanlık tarihi için önemi ve rolü nedir?" sorusuna bir cevap olmak üzere, hitabetin tanımı, amacı, önemi, sanat yönü, belâgatle ilişkisi, çeşitleri ve eski Yunan, Roma, Türk ve İslam öncesi Arap hitabetini ele almaya çalışalım.

\section{Hitabet Sanatı}

\subsection{Hitabetin Tanımı}

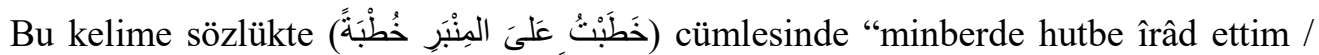

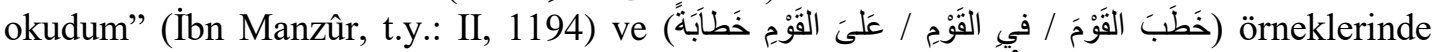
görüldüğü üzere "insanlar karşısında hitap etmek, konuşmak" (Âyid v.d., 2003: 404) veya gibi mastar olarak kullanılan (خَطْابَ) lafzı ile de, maksadını muhataba bildirmek, anlatmak ve delil ile ikna etme (Mahfûz, t.y.: 13) anlamlarında kullanılmıştır. Bu tanımlar 1şı̆̆ında hitabet lügat yönünden, topluluğa hitap ya da cami vb. dinî mekânlarda cemaat karş1sında hutbe ile vaaz gibi dinî konuşmalar icra etmektir. Arap dili gramerinde (ََْْطُبُ

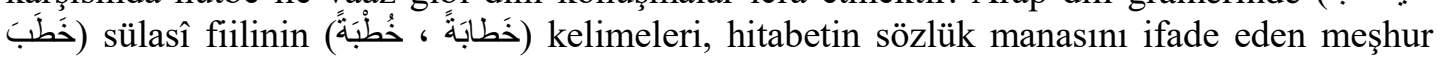
mastar kalıplarıdır (Mucemu'l-Vasît, 2004: 242).

Arapça kaynaklı lügatlerde veya kitaplarda, hitabeti ifade etmek maksadıyla genellikle (خَطُبَّة) mastar ismi (Âyid v.d., 2003: 404; İbn Manzûr, t.y.: II, 1194; Mahfûz, t.y.: 13; Mucemu'l-Vasît, 2004: 242), Osmanlı Türkçesinde (خطابَة) kelimesi daha yaygın olarak kullanılmaktadır (Sami, 1998: 584). Yukarıda gördüğümüz gibi hitabetin karşılığı olan lafzın aslı "hatâbet" tir. Esasında Arapça ve Türkçede bu iki kelimenin kullanımında yadırganacak bir durum yoktur. Çünkü "hitabet" kelimesi, sarf ilmî yönünden, sülasî fiillerin semaî mastar

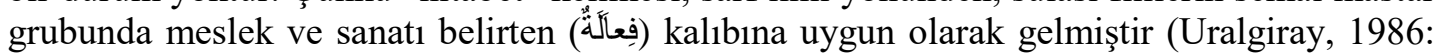
II, 918).

Hitabetin terim veya 1stılahî yönden de farklı tanımları yapılmaktadır. Hitabet, nutuk anlamına kullanıldığı gibi, söz sanatı manasına gelen retoriği (TDK, 2017) karşılayan bir kavram olarak da ifade edilmektedir. (Serinsu v.d., 2009: 141) Bir kısım uzmanlar hitabeti, insanların fikir, dava vb. durumları diğer insanlara duyurmak maksadıyla kullanılan araç (Çakan, 1998: 15) olarak açıklarken, bazıları da "muhatabı etkileme sanatı" (Doğru, 2000: 15) olarak görüp onun sanat yönüne vurgu yapmaktadırlar. Bunlardan biraz daha farklı açıdan, "fesahati kullanarak selis (akıcı) bir üslup ile nutuk îrâd etme" (Sami, 1998: 584) şeklindeki tanım ise, hitabetin fesahatle olan ilişkisine işaret etmektedir. Bir sözün; lafiz, mana ve ahenk yönünden mükemmelliği veya kusursuzluğu, onun fesahatini göstermektedir ki bunun daha ileri seviyesi belâgattir (Yeğin, 2008: 279). Fasih ise, fesahatli olanı veya fesahate uygunluğu ifade etmektedir. Lafzı kolay, dokuması (kelimeler arası örgüsü) gayet iyi, kıyas üzere sarfa uygun, akıcılığı tatlı, manası apaçık ve anlaşılır olan bir kelam fasihtir (Cârim ve Emin, 2010: 5).

Arap Edebiyatında hitabeti karşılayan ve onsuz hitabe sanatının icra edilemeyeceği diğer bir kavram da inşâd sanatıdır. İnşâd, muhatabın huzurunda kendisinin veya başkasının 
eseri olan manzum ya da mensûr bir metni okuma ya da beyan etme sanatı olarak isimlendirilir. (Mâcit, 1912: 13) Bundan dolayı, Arap şairlerinin devrinin ekâbirine (kavmin ileri gelenlerine) kasideleri inşâd ettiği etkili sunumları karşılığında çok yüklü hediye ve bahşişler aldıkları belirtilmektedir (Sami, 1998: 178). Buna benzer farklı bir ifade ile inşâd, topluluğun karşısında usulünce şiir okuma anlamında da kullanılır (Pala, 2000: 22, 342).

\subsection{Hitabetin Konusu ve Amacı}

Her türlü konuda söz sarf edilebileceği için, hitabetin tayin edilerek sınırlandırılmış belli bir konusu bulunmaz (Çetin, 1998: 5). Hâlin muktezasına göre her mevzu, hitabete konu olabilir. Dinî hitabetlerin yegâne ve değişmeyen konusu İslâm'dır (Çakan, 1998: 16, 19).

Hitabetin tanımında onun amaçları da göze çarpmaktadır. Topluluk karşısında bir fikri izah etme, bir amacı anlatmak, öğüt vermek, muhatabına bir görüşü benimsetmek, bir fiile teşvik vb. maksatları gerçekleştirmek üzere güçlü ve etkileyici hitap veya konuşmalar, hitabetin genel manasını özetlediği (Kaya, 1998: 18, 156; Serinsu vd., 2009: 141) gibi onun amaçlarına da işaret etmektedir.

Hitabetin tanımı açısından farklı amaçları vardır. Mesela, hitabeti güçlü ve etkileyici konuşma olarak belirten bir görüş çerçevesinde hitabetin amac1, "bir ülküyü veya fikri, bir gruba benimseterek bunun ile dinleyenleri harekete sevk etme (Doğru, 2000: 17) ya da "topluluk karşısında bir fikri izah etme, bir amacı anlatmak, öğüt vermek, bir fiile teşvik vb." olarak belirtilir (Kaya, 1998: 18, 156). Ayrıca hitabetten amaç; bir konuda muhataba bilgi vermek, insanları eğlendirmek ve onları belli bir yöne sevk ve ikna etme, (Çakan, 1998: 16) bir fikir veya görüşe inandırmak, heyecana sevk etmek ve duygulandırmaktır (Uzun, 2000: 145).

Hitabeti, insanların ihtiyacını ve görüşlerini başkalarına duyurmak için kullanılan araç (Çakan, 1998: 15) olarak tanımlayan diğer bir görüsse göre de, bilhassa dinî hitabetten maksadın onun hedef değil, muhataplarla olan karşılıklı ilişkilerini ve iletişimlerini sağlayan âdeta bir araç şeklinde görülmesidir (Çetin, 1998: 6).

\subsection{Hitabetin Önemi}

Peygamberler, Allah tarafindan tevdi edilen ilahi görev çerçevesinde, iman ve güzel ahlak esaslarını, sorumluluk dâhilindeki insanlara anlatmakla, tebliğ görevini yerine getirmişlerdir. Bu konuyu ifade eden bir Kur'an-1 Kerim ayeti mealen şöyledir: "Ey Peygamber! Rabbinden sana indirileni tebliğ et. Eğer bunu yapmazsan onun verdiği peygamberlik görevini yerine getirmemiş olursun..." (Mâide 5 / 67) Tebliğ görevini yerine getirmek, muhataplarla konuşmak ve karşıl1klı iletişim kurmak demektir ki bu da ancak hitabetle mümkün olmaktadır. Ayrıca peygamberler, dini anlatırken ve muhatapların sordukları meseleleri açıklarken kendi milletlerinin dilleriyle konuşmuşlardır (Çakan, 1995: 249). "Biz her peygamberi, ancak kendi kavminin diliyle gönderdik ki, onlara (Allah'ın emirlerini) iyice açıklasın..." (İbrâhîm 14/4) mealindeki ayet, bu hakikate işaret etmektedir.

İslâmîyet'in iki temel esası, Kur'an-1 Kerim ve sünnettir. Esasında sadece bu iki ana kaynaktaki prensipler bile, hitabetin önemi ve beşer hayatında oynadığı rolü göstermektedir. Kur'an'daki bazı ayetlerde ve Hz. Peygamber'in bazı hadislerinde, hitabetin önemi 
vurgulanmıştır. Mesela: “(Ey Muhammed!) Rabbinin yoluna, hikmetle, güzel öğütle

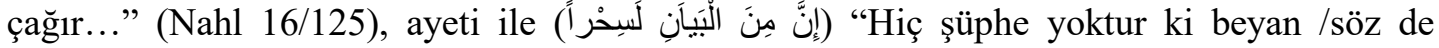
büyüleyici bir tesir vardır.” (Buhârî, 2010: H. N. 5146) vb. hadisler, hitabetin taşıdığı önemi ve değeri göstermektedir.

Allah, insanları tanışsın ve görüşsün diye ayrı ayrı kabilelere ayırdığını belirtmektedir. "Ey insanlar! Şüphe yok ki, biz sizi bir erkek ve bir dişiden yarattık ve birbirinizi tanımanız için sizi boylara ve kabilelere ayırdık..." (Hucurât 49/13) mealindeki Kur'an ayeti, bu konuyu yansıtmaktadır. $\mathrm{Bu}$ ayette de beyan edildiği üzere karşılıklı görüşmek ve konuşmak için de yine hitabete muhtacız.

Ak1l ve konuşmak kabiliyeti, insanları diğer varlıklara üstün k1lan özelliklerdendir. Akıl yürütmekle bulduğumuz hakikatlerin ve düşüncelerin söze dönüştürülerek insanlara ulaştırılmasında konuşmaya ihtiyacımız vardır (Doğru, 2000: 18). Yaratılışı gereği sosyal bir varlık olarak insan, muhataplarıyla iletişim hâlindedir. Sözlü iletişimi başarılı ve etkili yapan faktör ise, iletilecek hususların belli bir metot üzere ve bir hedef çerçevesinde planlı sunumu ve dilin hassasiyetini ve inceliğini göz önüne alarak icra edilecek konuşmadır (Ekşi v.d., 2012: 31).

Hatip ile muhatabı ya da verici ile alıcı arasındaki ortak öğe olan dilin bulunması, hitabetin anlaşılır olmasının temel şartıdır. Tebliğ ve irşad konusunda düzgün konuşmak veya dilin iyi kullanılması çok önemlidir. Bundan daha önemlisi de tebliğ yapanların bu vazifeyi içtenlikle benimseyerek yerine getirmesidir. Gayr-i ciddi ve samimiyetten uzak hitaplar, hitabetin tekniğine göre mükemmel olarak hazırlansa bile ya arzu edilen müspet bir sonuç doğurmaz ya da dinleyicileri etkilemez (Çakan, 1995: 249). Samimi bir üslup, hitabetin önemi ve değerini vurgulayan esas unsurlardandır. Neredeyse isyan derecesine kadar gelen ordusuna icra ettiği bir hitabe ile Çaldıran Zaferi'ne vesile olan Yavuz Sultan Selim ve daha niceleri, toplulukları ikna eden inandırıcı lisanlarıyla, orduların muzafferiyetine bir zemin hazırlamışlardır (Doğru, 2000: 20).

Hitabetin başarısında onun tekniğinin iyi bilinmesi ve ustaca kullanılması önemli bir faktördür. Zira hitabetin temel kurallarına ve tekniğine uyulmadan icra edilen bir hitabetin başarılı olması mümkün değildir. İnsanlık tarihi incelendiğinde hatiplerin, insanlar üzerinde büyük bir etki gücüne sahip olduğunu, farklı medeniyetlerin ortaya çıkmasında ve gelişmesinde önemli hizmetleri ve katkılarıyla kahraman hüviyetini kazandıkları bir gerçektir. Hatta büyük hatipler, genellikle, cemiyetlerin buhranlı devirlerinde ortaya çıkmışlardır (Uzun, 2000: 146).

\subsection{Hitabet Güzel Sanattır}

Sanat dalları olan mimari, resim, müzik vb. gibi hitabet de güzel sanatlardandır (Çetin, 1998: 5). Bu bağlamda hitabeti bir sanat olarak değerlendirdiğimizde onun, sanatkâr (hatip) ile muhatabı olan dinleyicinin iç içe bulunduğu (Kazancı, 1980: 21) "güzel konuşma" sanatı olarak varlığını sürdürdügü (Uzun, 2000: 145) ifade edilebilir.

Arapça gramerde sarf ilmine göre (فِقَآلَّة) mastar kalıbı, meslek grupları veya bir sanat dalını belirtmektedir (Maksudoğlu, 2005: 70). Buna göre (خِطَبَّة) kelimesi hatiplik sanatını veya mesleğini belirtmek için kullanılan sülâsî mücerred bir mastardır (Uralgiray, 1986: II, 918). Çünkü bu fikri doğrulayan kaynaklara göre (صناعة الخطابة) kelimesinde, hitabetin 
maharete dayalı bir sanat ve meslek olduğu belirtilmektedir (Dozy, 1981: IV, 131). Yine ( فَنْ (الخَطابَة 404).

\subsection{Hitabetin Belâgatle İlişskisi}

Belâgatin "meanî, beyan ve bedî' konularını içine alan ve inceleyen ilim dalı" şeklindeki tarifi, onun edebî sanatlarla olan yakınlığını beyan etmektedir (Kılıç, 1992: 5, 380). Diğer bir tarife göre belâgat muktezayı hale uygun söz söyleme sanatıdır (Yeğin, 2008: 115). Beliğ ise, belâgatin kurallarına ve tarifine uygunluğu içine almaktadır. Söylendiği konuma ve hitap ettiği şahıslara uyumuyla insan ruhunda cazibedar (çekici) etki uyandıran ve muktezayı hâle mutabakatı olan her kelam, beliğdir (Cârim ve Emin, 2010: 8-9).

Etkili ve güzel konuşma sanatı olan hitabetin tarifinde göze çarpan farklı bir bakış açısı ise onun retorikle ilişkili olmasıdır. (Kaya, 1998: 18, 156; Serinsu vd., 2009: 141) Hitabet manasına gelen retorik, etkili ve güzel konuşma sanatıdır (Kaya, 1998: 18, 156). (TDK, 2017) Retoriğin belâgatle yakın bir ilişkisi vardır. Bu bağlamda "söz sanatlarını inceleyen bilim dalı" şeklindeki tanım ile retoriğin belâgate yakınlığı ve "güzel söz söylemeyi ifade eden bir sanat" olarak tanımı da retoriğin hitabetle olan ilişkisini belirtmektedir (TDK, 2015).

İslâm mantıkçılarının "Kitâbü'l-Hatâbe" adıyla tanıdığı Aristo'nun (ö. M.Ö. 322) (Kaya, 1991: 3, 375) ünlü "Rhetorica" isimli eseri, meşhur eski hatiplerin birikimini ve Aristo'nun görüşlerini yansıtması, hitabet ve belâgatle ilgili konulara yer verilmesi bakımından hitabeti sistematik olarak ifade eden bir kitaptır (Kaya, 1998: 18, 156-157). Ayrıca belagatin terim olarak "meleke" ve "ilim" olmak üzere iki manası bulunmaktadır. Batı dillerinde belâgate karşılık "rhétorique" kelimesi ilim anlamına kullanılmıştır (Kılıç, 1992: 5, 380).

İslâmî edebiyatta el-Kindî (ö. 252/866 [?]) "retorik" terimine karşılık olarak "belâgat"i kullanarak bu konuya ilk dikkat çeken kimsedir (Kaya, 1998: 18, 157).

İslâm ilim ve edebiyat tarihinde, hitabetle yakın ilişkisi olan belâgatin beyan ve bedi ilmine dair meselelerini ayrıntılı olarak ele alması yönünden Abdü'l-Kâhir Cürcânî'nin "Esrârü'l-Belâga" isimli kitabı, bu sahada kayda değer en meşhur eserlerden birisi olma özelliğine sahiptir (Kılıç, 1995: 11, 435).

Yukarıdaki ifadeler ışığında, kısaca belirtmek gerekirse retoriği, belâgatin sınırları içinde söz sanatlarıyla ilgilenen bilgi dalı ve hitabete göre, edebî kaidelere veya söz sanatlarına riayet ederek muhatabı ikna edebilecek derecede etkili, iyi ve güzel söz söylemek sanatı şeklinde tanımlayabiliriz.

\subsection{Hitabetin Çeşitleri}

Eski Yunanlılar, zamanı esas alarak hitabeti hazır zaman, istikbal ve mazi olarak üç bölüme ayırmıştır. Onlara da tesbîtiyye (ispat edip doğrulama) veya beyâniyye, şûrâ (istişâ̂î meclis) ve kazâiyye ismini vermişlerdir. Birincisi, şuandaki zamanı ifade eder ki methetme ve rağbet verdirme veya yermek ve nefret ettirmek için istişareye mahsus olan hitabettir (Mahfûz, t.y.: 69). Törenlerde hatiplerin genellikle övgü veya yergi konusunda icra ettiği 
konuşmaları içine alan tören ile ilgili hitabetler de Aristo'nun dinleyiciyi ve zamanı göz önüne alarak bahsettiği üç farklı hitabetten hazır zamana dâhil olan hitabeti göstermektedir (Kaya, 1998: 18/157).

İkincisi, geleceğe dair olan hitabettir. Milletin menfaatini celbedip zararı defetmek, harp ya da barışa teşvik ve halkın üzerinde yürüyeceği kanunlar koymak için dinleyiciyi sevk ve teşvik gayesiyle icra edilen hitabettir (Mahfûz, t.y.: 69). Aristo'nun tanımladığı siyasî hitabet de istikballe ilişkili olan bu hitabete işaret etmektedir (Kaya, 1998: 18/157).

Üçüncüsü, mazi ile bağlı hitabettir ki bundan maksat sanıkların suçsuzluğunu savunmak veya hâkimlerin sanıkları suçlu bulduğunda onları mahkûm edecek karar vermeleridir (Mahfûz, t.y.: 69). Aristo'nun ifade ettiği dava konusu olarak zikredilen ve geçmişte kalmış olan meseleyi gösteren adlî hitabeti de maziye yöneliktir. Aristo, dinleyiciyi ve zaman unsurunu nazara alarak, siyasî, adlî ve törenlerle ilişkili olarak üç farklı hitabetten bahsetmektedir. Demostenes, Cicero (Çiçero) ve Perikles, Eski Yunanlılarda Aristo'nun ifade ettiği üç tür hitabette meşhur olan hatiplere örnek olarak zikredilebilir (Kaya, 1998: 18, 157).

Hitabetin yukarıda geçen bölümlerini Aristo ortaya koymuştur. Aristo'nun taksiminde dinî hitabet yer almamaktadır. Belki o, yaşadığı asırda halkın sosyal şartları, kültür faktörleri veya inanca dair terimlerin az kullanılması gibi sebeplerle dinî hitabetten bahsetmemiştir. Sonradan sivil, siyasî ve dinî hayat tarzının gelişmesi, hitabetin çeşitleri üzerinde değişikliğe gidilmesini iktiza etmiştir. Diğer bir ifade ile yeni amillere göre, üzerinde kararlılık gösterilen veya alışılan taksimat, sonradan ilmî, siyasî, adlî, askerî ve dinî bölümler olarak geliştirilmiştir (Mahfûz, t.y.: 69). Bazı edebî kaynaklar, hitabeti siyasî, dinî, mehâfil hutbe (hitabe) leri diye üç bölüme ayırmaktadır. Münazara ve karşılıklı soru-cevap usulü hitabe mehâfile, zahidlerin sözleriyle vaazları ve mutasavvıfların kelamı ise, dinî hitabete dâhildir (Şelbî, 1987: 327).

Hitabetin türlerini belirlemek için, genellikle onun konuları ve şekilleri temel alınır (Çetin, 1998: 15; Doğru, 2000: 16, 63; Kazanc1, 1980: 21, 24). Üslubuna etki eden özellikler yönünden genellikle dinî, hukukî, ilmî (akademik), askerî ve siyasî olarak beş bölüme ayrılması, ilmî çevrelerde kabul gören en yaygın şeklidir (Doğru, 2000: 63). Yukarıda beyan edilen genel açıklama çerçevesinde hitabetin bölümleri şekil açısından değil, araştırmamızla ilgili olan konuları yönünden ifade edilecektir.

\subsubsection{Hukukî (Adlî) Hitabet}

İnsanlar, yaratılışı gereği sosyal bir hayata muhtaçtır. Sosyal hayat ise hukuk kuralları içinde kendisini ifade eder. Nerede bir insan topluluğu varsa, orada hukuk ilişkisi vardır. Mahkemelerde adaletin gerçekleştirilmesi maksadıyla icra edilen hukukî savunmalarda, hitabetin oynadığı rol tartışılamaz.

Hukuk ile ilgili konuşmalar bu nevi hitabetin temelidir. Savcıların hazırladıkları iddianameler, avukatlar veya maznunların (sanıkların) savunmaları ve muhakeme kararnameleri hukukî hitabetin örnekleridir (Kazanc1, 1980: 23). Kanunların tanıdığı imkânlar çerçevesinde, haksızlığa maruz kalan masum ve mazlumları savunmak maksadıyla mahkemelerde icra edilen konuşmalar, (Kazanc1, 1980: 24) hukukî hitabeti teşkil etmektedir. 


\subsubsection{Akademik (ilmî) Hitabet}

İlmî mevzularla ilgili olarak belli bir konu üzerindeki uzmanların icra ettiği konuşmalar, (Çetin, 1998: 15) akademik hitabettir. Mesela, fikrî bir konuyu izah, tez savunması, araştırmalar hakkındaki konuşmalarla akademisyenler tarafından toplumun aydınlatılması, akademik hitabetin konularıdır. Bilhassa üniversite dersleri, ilmî konferanslar vb. akademik konuşmalarda heyecandan ziyade ilmî bir dil ve dinleyici kitlesini ikna eden bir üslup kullanılır (Doğru, 2000: 64).

\subsubsection{Askerî Hitabet}

Askeri gayret ve heyecana teşvik ederek manevi yönden güçlendirmek için komutanların yaptıkları veciz ve özlü konuşmalar, askerî hitabeti teşkil eder (Doğru, 2000: 73). Askerî hitabeler veciz, kısa ve kuvvetli olmalı (Kazancı, 1980: 22); askere güç ve moral vermekle, onları savaşa sevk edip cesaretlendirmelidir (Çetin, 1998: 16).

\subsubsection{Siyasî ve Diplomatik Hitabet}

Siyasî hitabet, parlamentoya dayalı rejimlerde politikacı ya da milletvekillerinin, siyasete dair konuşmalarıdır. Bu konuşmalar genellikle ya politika hususunda halkı aydınlatma ya da vatandaşın oylarını kazanmak maksadıyla icra edilir (Çetin, 1998: 15). Diğer bir ifade ile bunlar, siyasî gaye ve fikirlerin ya da bu konudaki programların geniş halk kitlelerine iletilmesi için icra edilen hitabelerdir. Siyasî hitabetlerde açık ve sade bir üslup kullanılır (Doğru, 2000: 76).

Uluslararası münasebetlerde diplomatik nezaketi gösteren kurallar çerçevesindeki hitaplar, diplomatik hitabeti teşkil etmektedir. (Çetin, 1998: 16) Bu hitabetler, diş işleri bakanlığına mensup diplomatik görevliler tarafından icra edilir. Mesela, devlet adamları ve hükümeti temsil eden yetkililerinin havaalanları vb. yerlerdeki demeçleri ve basın toplantıları, ülkemize gelen heyetleri karşılama ve uğurlamada icra edilen konuşmalar, siyasî veya diplomatik hitabete örnektir (Doğru, 2000: 77).

Diplomatik hitabetlerde devletlerarası ilişkilere, ülkelerin çıkarlarına dikkat edilerek, (Çetin, 1998: 16) çok yönlü hassas dengeleri hesap ederek itina ile seçilmiş ve yoruma müsait olan ifadeler kullanılır. Her ne kadar diplomatik hitabeti ayrı bir çeşit olarak ele alsak bile esasında bu hitabetin muhtevası, siyasî hitabete daha yakındır. Bu hitabeti, siyasî hitabetin bir çeşidi veya şubesi olarak görmek daha doğru olacaktır (Doğru, 2000: 77). İkisinin farkı ise, diplomatik hitabetin çoğunlukla dış siyasete müteallik hususlarla ilişkili olarak devletin resmî görevleri çerçevesinde icra edilmesi, diğerinin daha genel ve her türlü siyasî konulara şamil olmasıdır.

\subsubsection{Dinî Hitabet}

Din görevlileri tarafindan veya ilahiyat alanındaki uzmanlarca (Ekşi v.d., 2012: 32) mabet (cami) içi ve haricinde dinî konuları, muhataba ilan edip öğretmek ve uygulama maksadıyla icra edilen konuşmalar, dinî hitabeti teşkil etmektedir. (Doğru, 2000: 82) Genel olarak dinî hitabetin konusu dini meselelerdir (Çakan, 1998: 19). 
Buna göre dinî hitabeti tatbikat veya uygulama sahası yönünden mabet içi ve dış1 şeklinde iki gruba ayırabiliriz (Çakan, 1998: 25). Hutbe ile vaaz, genellikle cami, mescit vb. ibadet mekânlarında tatbik edilen mabet içi hitabettir.

a) Hutbe: lügat yönünden Araplarca secili nesir veya mensur bir kelamdır (Fîrûzâbâdî, 2008: 478; İbn Manzûr, t.y.: II, 1195). Seci, edebiyatta nesrin kafiyesi (Yeğin, 2008: 877) veya nesir içindeki kafiyedir (Durmuş, 2009: 36, 273). Istılahî yönden ve konumuzla ilgili genel bir tarife göre hutbe; önceliği cuma ve bayram namazlarında olmak üzere bazı ibadet ve törenlerin ifasında topluluk karşısında icra edilen konuşmadır (Serinsu v.d., 2009: 147). Hutbe faaliyetine hatiplik, hatiplik görevini icra eden kişiye de hatip denir (Çetin, 1998: 188). Fakihlerin görüş birliği çerçevesinde hutbe, cuma namazının sıhhat şartlarındandır. Hutbenin kısa tutulması sünnettir (Algül v.d., 2002: I, 299, 301) .

İslâm Peygamberi Hz. Muhammed (s.a.v.)'in Mekke'den Medine'ye hicretiyle başlayan hutbe, günümüzde dinî hitabetin en yaygın türü olarak hâlen devam etmektedir. Peygamber Efendimiz ve Râşid halifeler devrindeki hutbeler dinî, sosyal, askerî vb. hususlarda îrâd edilir, tebâyı ilgilendiren farklı durumlarda devletin resmi görüşleri belirtilir ve halk aydınlatılırdı. Sonradan adlî teşkilatın esası konumundaki kadılara ve din görevlileri olan imamlara bırakıldığında, hutbelerin ağırlığını dinî mevzular teşkil etmiştir (Çetin, 1998: $13,14)$.

Hatiplik, genellikle Râşid halifeler ve Emeviler döneminde, halifeler ve tayin ettiği valilerin icra ettiği temel görevlerdendi. Abbasi halifesi Harun Reşid devrinde bu iş, kadılara terk edilmiştir. Osmanlılarda, halifelik makamındaki sultanın, hatiplik vazifesini üstlenen "hatip" unvanına sahip özel görevliler atanmıştır. Cumhuriyet döneminde ise camide din görevlisi olan imam, hatiplik vazifesini de uhdesine alarak (Çetin, 1998: 13) "imam-hatip" unvanıyla isimlendirilmiştir.

b) Vaaz: Hitabetin tekniğine uyularak din görevlileri tarafından cemaat karşısında öğüt vermek anlamındadır (Çakan, 1998: 59). Diğer bir ifade ile vaaz; kişileri hayır üzere iyilik etmeye yöneltmek gayesiyle nasihat etmek demektir. Kur'an-1 Kerim'deki ayetlerde vaaz kavramına ait misaller çoktur (Lokman $31 / 13$ ). Bu yüzden Peygamberlerin tamamı ve özellikle Hz. Peygamber (s.a.v.) Efendimiz, yaygın eğitimin vazgeçilemez bir öğesi olan vaaz metodundan yararlanmıştır (Serinsu vd., 2009: 375).

Bazı Kur'an ayetlerinde vaazın lüzumundan bahsedilmektedir. Mesela "Sen yine de öğüt ver. Çünkü öğüt müminlere fayda verir." (Zâriyât 51/55) ayetinde müminler için öğüt vermenin yararına işaret edilmektedir. Ayrıca şu ayet mealleri de (Gâşiye 88/21-22, A'lâ 87/9-10, Kâf 50/45) İslami toplumda vaazın gereğine işaret etmektedir (Çakan, 1998: 60). Vaaz etme işini yapan ya da vaaz vermek görevini üstlenen din görevlileri vaiz unvanını alır. (Çetin, 1998: 242) Kur'ân -1 Kerîm'deki ayetlerde vaaz kelimesi geçmez, (Çakan, 1998: 59; Cirit, 2012: 42, 404) vaazın yerine mev'iza tâbiri kullanılır. Mev'iza, dinî ögüt, vaaz ve nasihati karşılayan bir kavramdır (Çakan, 1998: 59; Çetin, 1998: 242). Bu konuya işaret eden “(Ey Muhammed!) Rabbinin yoluna, hikmetle, güzel öğütle çağır...” ayetinde (Nahl 16/125) mev“iza "öğüt" anlamına kullanılmıştır (DİB, 2015).

Dinî hitabetin diğer bir türü de mabet dış1 hitabettir(Çakan, 1998: 25) ki bunlar genellikle cami veya mescit haricinde uygulanır. Geniş çaplı katılımların olduğu ve umumi 
olarak halka açık veya özel mekânlarda sohbet şeklinde icra edilen dinî hitabetler, medya ile icra edilen yayınlar, (Ekşi v.d., 2012: 36) vb. örnekler, mabet dış1 hitabetin örneklerindendir.

Hitabeti şekil yönünden de çeşitlere ayırabiliriz. Araştırmamızın konusuna girmeyen bu bölümü, yalnızca isimlerini ifade ederek geçeceğiz. Şekil açısından hitabetler, konferans, panel, (Ekşi v.d., 2012: 36; Kazanc1, 1980: 25, 27) hitabe, nutuk, sohbet (musahabe), (Kazanc1, 1980: 24, 25) muhavere, açık oturum, müzakere (tartışma), münazara (Yavuz, 2006: 31, 576) sempozyum (Kazanc1, 1980: 24-27) olarak zikredilebilir.

Kısaca özetlersek, genellikle konularına göre ilmî (akademik), hukukî, askerî, siyasî, dinî (Doğru, 2000: 16, 63; Ekşi v.d., 2012: 31-32) ve resmî ya da özel merasimlerde icra edilen konuşmalar (Ekşi v.d., 2012: 32; Uzun, 2000: 145) edebî kitaplarda en çok göze çarpan hitabe çeşitleridir. Konuları ve türü ne olursa olsun esasen hitabette ortak nokta, hitabetin gayet açık, inandırıcı olması ve muhatabı olan dinleyenleri sıkmamasıdır (Özön, 1954: 123).

\section{Hitabetin Tarihçesi}

Hz. Âdem'in eşya isimlerini meleklere söylemesi, ${ }^{2}$ onun ilk insan olarak konuşmasının veya muhataba hitap etmesinin ilk örneğidir (Doğru, 2000: 23). İnsanoğlunun yaratılışından bu yana sosyal hayatı paylaşan insanlar, her zaman hitabetin etkisine ve gelişimine şahit olmuştur.

Hitabetin genel tarihi içinde Eski Yunan ve Romalıların hitabeti, ayrıcalıklı bir konuma sahiptir. Zira Avrupa kültürünün üzerinde Yunan ve Roma unsurları hâkim oldukları gibi, Yunan ve Roma kültürünün Avrupa üniversite programlarında ve doğu kültüründe küçümsenemeyecek derecede büyük rol oynadığı da tarihi bir gerçektir. Ayrıca her iki milletin edebi kültürü, Avrupa'daki modern kalkınmanın temelinde etkili olmuştur (Şelbî, 1987: 142).

Araştırmamızın bu bölümünde, sırasıyla Eski Yunan, Roma ve Türk hitabetinden kısaca, Câhiliye dönemi Arap hitabetinden de daha geniş ve ayrıntılı olarak bahsedeceğiz.

\subsection{Eski Yunanlılarda Hitabet}

Hitabetin en eski örnekleri, eski Yunanistan'da ve Latinler'de göze çarpmaktadır. Eski Yunanlar ve Latinler, edebiyatın çok önemli bir şubesi olan hitabete ileri seviyede ehemmiyet ve değer vermiş̧ir (Kazanc1, 1980: 29). Hitabetin tarihi konusunda bilgi ve belgelere en çok sahip olduğumuz devir, eski Yunan dönemidir. Milattan önceki 4. y.y. da Yunanlılarda insanların, bir çeşit demokrasi idaresine sahip olduğu Atina şehrindeki Agora adını verdikleri geniş ve açı meydanlar, halkın problemlerinin yine halk tarafından rahatlıkla tartışılarak karara bağlandığı yerlerdi.

Eski Yunanlılarda halkı idare etmek, ancak onları ikna etmeye bağlıydı. Bundan dolayı Atina'nın büyük siyasetçileri halkın meşhur hatipleriydi. Agora meydanlarındaki konuşmaların halk tarafından ilgi ile takip edilmeleri, o devirdeki insanların güzel söz ve

\footnotetext{
2 “Ta'lîm-i Esmâ" hakikati için bk. Bakara suresi, 2/31-33. ayetleri.
} 
etkili hitabete olan düşkünlüğü, eski Yunanistan'da hitabetin gelişmesi ve buna bağlı olarak da hatip yetiştiren okulların açılışına sebebiyet vermiştir (Kazanc1, 1980: 30).

Milattan önceki devirlerde bilhassa Yunanlılarda hitabet, hem bir sanat dalı hem de iyi gelir sağlayan bir meslek olarak revaçtaydı. Eski Yunan şehir devletindeki halk meclisinde temsil edilen kesimlerin çıkarlarını başarıyla savunmak, hitabette liyakatli, mahir ve üstün hatip olan politikacılara bağlıydı. Aristo'nun ünlü "Rhetorica" isimli eseri, (Kaya, 1998: 18, 156) Eski Yunanlıların hitabet sanatına değer verdiğini ifade eden ve edebiyat tarihine 1şık tutan tarihi bir vesika olma özelliğini taşımaktadır. Tarihî kaynaklara göre, eski Yunanistan'da hitabete yön veren ve bu ilmi sistemleştiren hatiplerin yetiştiği ifade edilmektedir. Demosthenes / Demosten (ö. M.Ö. 322), Perikles (ö. M.Ö. 429) (Çetin, 1998: 12), Eşin (ö. M.Ö. 313) (Kazanc1, 1980: 30), Ksenofon (ö. M.Ö. 335) ve İzokrates (ö. M.Ö. 338) (Göçgün, 2004: 42) eski Yunanlıların meşhur hatiplerindendir.

\subsection{Eski Roma'da Hitabet}

Edebî kaynaklar, eski Yunan döneminde olduğunu gibi Roma'da da hitabetin ileri seviyede olduğu belirtmektedir. Roma'da "forum" adını alan açı meydan, siyasî ve sosyal problemlerin müzakere edildiği ve halkın bu tartışmaları takip ettikleri bir yerdi. Ayrıca Eski Roma Senatosu da adeta bir hitabet meclisi özelliğindeydi (Çetin, 1998: 12). İdarecilerin halkı ikna edebilmeleri ve senatodaki halk temsilcileri grubunun meselelerini idarecilere kabul ettirebilmek noktasında usta bir hatip olmalarını gerektiriyordu (Doğru, 2000: 26).

Eski Roma'da hitabeti zirve derecesine çıkaran ve bu sanatı geliştiren hatipler vardır. Çiçero / Cicero (m.ö. 106-43), Genç Plin (m.ö. 113-62), İhtiyar Seneca (m.ö. 55-m.s. 41) meşhur Roma hatipleridir (Doğru, 2000: 26; Kazanc1, 1980: 30).

\subsection{Türklerde Hitabet}

İslamiyet'ten önceki Türk hitabetini aydınlatan bir takım tarihi kaynaklar bulunmaktadır. En eski Türk dili metinlerinin yazılı olduğu Orhon kitabeleri, bunun örneklerindendir. Bilhassa Bilge Kağan'ın kendi halkı ve beylerine hitap ettiği bölümler, gayet dokunaklı bir ifade gücüne sahiptir. Bu bakımdan Orhon kitabeleri, Türkçenin en eski nesir ve hitabet örneğini gösteren (Kaçalin, 2007: 33; 390, 392) tarihi vesikalardır. İslam'a girmeden önceki dönemlerde icra edilen ve bilhassa evlenmek, ad koymak vb. törenlerde hitabeler yapılması, Türklerin sosyal hayatında zengin bir tören hitabeti olduğunu göstermektedir. Buna dair örnekler; Türklerin efsanevî hatibi olarak kabul edilen Dede Korkut'un hikâyeleri sayesinde günümüze kadar gelmiştir (Uzun, 1998: 18, 161).

İslam'1 kabul ettikten sonra, Türklerde hitabetin temelini dinî hitabetle gelen hutbe ile vaaz ve tasavvufî sohbetler teşkil etmektedir. Tasavvufta bir metot olan sohbetin ilk hatibi olan Ahmed Yesevî (XII. y.y.), en meşhur mutasavvıf veya sufî olarak kabul görmüştür (Uzun, 1998: 18, 160-161). Ayrica büyük bir mutasavvif olan Mevlânâ Celâleddîn-i Rûmî (ö. 1273), Yunus Emre (ö. 1320) ve millî mizah kahramanı olarak kabul gören Nasreddin 
Hoca (ö. 1284) da Müslüman Türk halkının arasında İslamiyet'in yaşanması ve yayılmasında vaazları ve nükteleriyle emeği geçen en meşhur hatiplerdendir. ${ }^{3}$

İslâmî Dönem'e girildiğinde Türk kültüründe halk arasında destanlar çokça okunurdu. Battalname, Ebû Müslimname, Dânişmendname, Hamzanâme, Saltuknâme, Dede Korkut Kitabı ve Oğuz Destanları Anadolu'da en çok rağbet gören destanlardandı (Şeşen, 2012: 41, 492). Tarihi kaynaklara göz attığımızda Ertuğrul Gazi ve Şeyh Edebâli’nin Osman Bey için yaptıkları nasihatler, Alpaslan'ın Malazgirt Zaferi henüz kazanılmadan, Fatih Sultan Mehmed'in ve Akşemseddin'in İstanbul kuşatmasında ve Yavuz Sultan Selim'in Çaldıran Seferi sırasında ordusuna îrâd ettiği dokunaklı hitabeler, Türk-İslâm hitabetini ifade eden meşhur örnek hitabeler (bk. EK-2) arasında gösterilebilir. Türklerin hitabette eski Yunanlılar ve Romalılar kadar isim yapmamasının en önemli sebebi, îrâd edilen hitabe veya sarf edilen şifahî sözlerin yazıya geçirilmemesidir (Uzun, 1998: 18, 160).

İslâmî Türk hitabeti, bilhassa Osmanlılar devrinde yazılı metinlerle ilerleme kaydederek farklı türleriyle gelişmeler göstermiştir. Bu çalışmanın ekinde (EK-2) "Alparslan ve Malazgirt Zaferi" isimli hitabe, Selçuklu dönemi İslami Türk hitabesini yansıtan örneklerdendir. Başlangıcından günümüze kadar geçen zaman diliminde, hitabette zirve yapmış seçkin hatipler arasında şu isimleri zikredebiliriz:

Alparslan, I. Murad, II. Murad, Akşemseddin, Fatih Sultan Mehmed, Yavuz Sultan Selim, Kanûnî Sultan Süleyman, Aziz Mahmud Hüdâyî, Barbaros Hayreddin Paşa, Sokullu Mehmed Paşa, Ahmed Cevdet Paşa, (Uzun, 1998: 18, 161) Fuad Paşa, Sultan Abdülaziz, II. Abdülhamid, Giritli Sırrı Paşa, Ahmed Vefik Paşa, Hasan Fehmi Paşa, Sadrazam İbrâhim Hakkı Paşa, Manastırlı İsmâil Hakkı, Mehmed Âkif Ersoy, Hasan Basri Çantay ve Bedîüzzaman Said Nursî (Uzun, 1998: XVIII, 162).

\subsection{Araplarda Hitabet}

Bu makalede Arap hitabetini çok yönlü değil ancak İslamiyet'ten önceki dönemlerde zirve yapan ve edebi litaratüre giren Cahiliye hitabetinden kısaca bahsetmek istiyoruz. Çünkü İslam hitabeti, çok yönlü bir araştırma konusunu teşkil etmektedir. Esasında Cahiliyede Arap edebiyatının iftiharı olan konu, meşhur Muallâka şairlerinin şiirleridir. Şiirin, hitabetten farklı bir edebi türe sahip oluşu vb. sebeplere bağlı olarak burada Cahiliye dönemi Arap şiirini değil yalnızca özet olarak Cahiliye Arap hitabetine dair konuları ele almaya çalışacağız. ${ }^{4}$

Arapların İslâm dininden önceki dinî, sosyal, ilmî ve kültürel yönden gaflet ve cehaletle geçirdiği hayata ve bu döneme "el-Câhiliyye" denir. Câhiliye, Hz. İsa'dan Hz. Peygamber (s.a.v.)'e kadar geçen zaman için özel bir tabir olarak (Demirayak ve Savran, 1993: 1-2, 135) İslâm'dan önceki dönemi ifade etmek için de kullanılır (Demirayak ve Savran, 1993: 1, 35). Diğer bir görüşe göre Câhiliye asrı, bir buçuk asır olan bir zaman

\footnotetext{
${ }^{3}$ Konu hakkında daha geniş bilgi için bk. DİA, Reşat Öngören, "Mevlânâ Celâleddîn-i Rûmî", XXIX, 441-448; Mustafa Tatc1, "Yûnus Emre", XLIII, 600-606; Nurettin Albayrak, "Nasreddin Hoca", XXXII, 418-420.

${ }^{4}$ Muallâka / Muallakāt konusunda daha geniş bilgi için bk. Süleyman Tülücü, "Muallakāt”, DİA, c. XXX, s.s. 310-312, İstanbul, 2005.
} 
dilimini ve İslâmîyet'in zuhuru ile sona eren bir dönemi içine almaktadır (Mahfûz, t.y.: 2122).

\subsubsection{Câhiliye Hitabetini Hazırlayan Sebepler}

Câhiliye devri hitabetinin Arap edebiyatındaki yeri tartışılamayacak kadar önemlidir. Arapların milletçe fesahate ve belâgate düşkün olmaları, Câhiliye döneminde hitabetin doğuşuna zemin hazırlayan en önemli bir faktördür (Kazanc1, 1980: 32). Hatta İslâmî hitabetin doğuşu sırasında, Câhiliye hitabeti toplum üzerindeki etkisini sürdürmüştür. Yani Câhiliye asrı hitabeti, İslâmî dönem hitabetinin şekillenmesini sağlayan temel unsur olmuştur. Câhiliye şiiri ve hitabetinin konuları, İslâmî hitabete uyarlanmış ve dinî bir kisve giydirilmiştir. Buna rağmen Câhiliye'deki Arap milletinin, bedevilik ve çöl hayatı şartlarından dolayı, çoğunlukla hitabetin genel işlerden çıkamadığı, yani dallanıp budaklanıp özel olarak ihtisasa giremediği ve hususiyet kazanmadığı da gözlenmektedir (Atıyye, 1936: 91).

$\mathrm{Bu}$ asırda hamiyet, nefis, mal ve namus müdafaası gayesiyle baskın düzenlemek, haseb ve nesep cihetinden üstünlük iddiasıyla şiir ve hitabetle müfâhare, güçlü bir kabile taassubu, yiğitlik, cömertlik, izzet, şeref, yardım, komşusunu himaye etmek ve zulmü kabul etmemekten ileri gelen özelliklerin şerefi gibi haykırışı ifade eden edebi hitabet, Arap toplumunda meşhur olmuştur. Bu bağlamda ifade etmeliyiz ki Câhiliye'de bir sözün, harpte çarpışma ve düşmanına hücum etmek gibi büyük bir değeri ve etkisi vardı. Câhiliye hitabeti, doğuştan kazanılan fitrî bir haslettir. Ayrıca sosyal hayat tarzı, onları hitabete davet eden amillerin başındadır. Gücünü, saygınlığını ve şerefini muhafaza, başarı veya yiğitliklerini ebedileştirmek ve mefahirini (övünç ve iftihar vesilesini) teyit etmek için, Câhiliye devrindeki çocukların lisanları, hitabetle açılırdı (Mahfûz, t.y.: 21-22).

Câhiliye kültüründe vaaz etmekten ziyade kasas tabir edilen kıssa anlatmak faaliyeti daha yaygındı (Uğur, 1986: 293). Her kabilenin şair ve hatibi kabile içindeki konumuna ve itibarına ilave olarak kassâs vazifesini de üstlenirdi. Kıssaların konusu da çoğunlukla "Eyyâmü'l-Arab"a dair savaşlar ve kahramanlıklardı. Hitabetle kasas, Câhiliye Arap kültüründe önemli bir rol oynamıştır. İslâmîyet'in gelişiyle kıssalar, yerini İslâmî rivayete terk etmiştir (Uğur, 1986: 294).

Câhiliye hitabeti, bu devrin fikri aktivite yönünü ifade etmektedir. Hatip, onlar için dili, fesahati, beyanı, kavminin haklarını savunması, koruması ve onlar adına konuşmak gibi sebepler yüzünden yüksek bir makam elde etmiştir. Hatip, âdeta kabilenin dili ve iftiharlarının vesilesi olan yüzü konumundaydı (Cevâd Ali, 1993: VIII, 771).

Cahiliye edebiyatındaki sağlam metinler, tatlı lafızlar, kalpleri etkisi altına alıyordu. Kus b. Sâide'nin hitabe örneğinde görüldüğü gibi (bk. EK-1), hitabette fasılalar olması ve hitabetin güzelliğini sergileyen seci $^{6}$, hatibi rahatlatarak manaları kolay elde etme imkânını sağliyordu.

\footnotetext{
${ }^{5}$ Eyyâmü'l-Arab: Câhiliye asrı ve İslâmiyet'in ilk zamanlarında Arap kabileleri arasında vaki olan savaşlar için kullanılan özel bir tabir. Bu konuda daha geniş bilgi için bk. Mehmet Ali Kapar, "Eyyâmü’l-Arab”, DİA, İstanbul, 1995, XII, 14.

${ }^{6}$ Seci: Nesirdeki kafiyeyi ifade eden bir terim. Bu konuda daha geniş bilgi için bk. İsmail Durmuş, "Seci”, DİA, İstanbul, 2009, XXXVI, 273-275.
} 
Arap camiasında müşahede edilen münakaşa, niza vb. olumsuzluklara rağmen, bir araya geldikleri, buluştukları ve karşılıklı hitabede bulundukları mekânlar da mevcuttu. Câhiliye döneminin halkı, birbirine iftiharla övünerek üstünlük iddia etmek için, hikmet ve belâgati içinde barındıran kabiliyetlerinin ürünlerini, toplanılan bu yerlerde ortaya koyuyorlardı (Mahfûz, t.y.: 21-22).

Yukarıda saydığımız amillerden dolayı, İslâmîyet öncesi Araplarda seçkin bir hitabetin varlığında yadırganacak bir durum yoktur. Çünkü hitabet, bir yönüyle toplulukları ilgilendiren hadiselerden meydana gelen etkileşimlerin eseridir. Arap toplumunda şiddetli tartışma ve çekişmelerin ortaya çıkmasıyla aralarındaki savaşlar kesilmemiş (Mahfûz, t.y.: 21-22) ve bu yüzden hitabet de devam etmiştir.

\subsubsection{Câhiliye Devrinde Meşhur Hatipler}

İslâmîyet'ten önce Arap kabileleri içinde, dünyadaki diğer emsalleriyle boy ölçüşecek kadar maharetli hatiplerin yetişmesi sebebiyle, hitabetin genel tarihi seyrinde Câhiliye Arap edebiyatı devri, üstün bir konuma sahiptir. Ayrıca Arap edebiyatı tarihinin kaydetmediği şair ve hatipler de çoktur. Bunlar ya meşhur olmadığı veya Arap edebiyatında zirve yapmadığı için eserlerinden çok azı günümüze kadar gelmiştir (Atıyye, 1936: 71).

Kaynaklara göre "Kus b. Sâide el-İyâdî (Âlûsî, 1314/1896: 149; Cârim ve Emin, 2010: 68; Safvet, 1933: I, 35-36; Zeyyât, t.y.: 20-22) (ö. 600), Eksem b. Sayfî et-Temîmî (Zeyyât, t.y.: 20) (ö. 9/630), Âmir b. Zarib el-Advânî (Hafâcî, 1412/1992: 174), Amr b. Ma'dî Kerib ez-Zubeydî (Fâhûrî, 1986: 126) (ö. 21/23-643), Hâcib b. Zürâre et-Temîmî (ö. 3/625 [?]), Kabîsa b. Nuaym (Hafâcî, 1412/1992: 174; Safvet, 1933: I, 274), Kays b. Âsım el-Minkarî (Câhiz, 1418/1998: 218) (ö. 47/667), Zi'l-İsba' (Zu'l-İsba') el-Advânî (Âlûsî, 1314/1896: 163)" câhiliye devrinde isim yapmış en meşhur hatiplerdendir.

Bu makalenin sonundaki ek bölümünde (EK-1) görüldüğü gibi " Kus b. Sâide elİyâdî'nin Ukâz Çarşısında İrad Ettiği Meşhur Hitabesi" isimli örnek bir hitabe, İslam öncesi cahiliye devri arap hitabesini yansıtan önemli örneklerdendir.

\section{Sonuç}

İletişimde öncü rolü üstlenen ve bir sanat dalı olan hitabetin, toplumların kültürüne, içinde bulundukları konuma ve şartlara göre farklılık arz ettiği müşahede edilmektedir. $\mathrm{Bu}$ bağlamda ele aldığımızda Eski Yunan, Roma ve Cahiliye döneminde Arapların hitabette ileri seviyede olduğu ve bu sanatı gayet ustalıkla ele aldığ 1 görülmektedir. Hitabetin tarihi seyri içinde bu görüşümüzü destekleyici yüzlerce örnek mevcuttur. Bilhassa Aristo'nun "Rhetorica" isimli eseri, bu konuda müracaat edilecek ilk edebi eserlerden biri olarak hitabet tarihindeki yerini almıştır.

İslam'a girmeden önce Cahiliye döneminde Arapların genel karakterini yansıtan fesahate ve belâgate düşkünlüğü, hitabetin doğuşuna zemin hazırlayan sebeplerdendir. Cahiliye hitabeti, sonradan İslâm hitabetinin şekillenmesini sağlayan en önemli amillerden birisi olmuştur. Ayrıca okuma yazma bilenlerin azlığı, halkın sözlü edebiyata teveccüh 
etmesi de, kabile şairliği ve hatipliğin Arap toplumunda en çok rağbet edilen bir meslek olduğunu göstermektedir.

Tarihi kaynaklara göre -yukarıda da ifade ettiğimiz gibi- her ne kadar Türk hitabeti, Yunan, Roma veya Arapların Cahiliye devri seviyesine erişememiş olsa da, İslam'a girmeden önce sözlü ve kısmen de yazılı hitabette küçümsenemeyecek derecede milli kültürümüzü aksettiren örnekler vardır. Türklerin İslam Dini'ne girdikten sonra, isimlerini buraya sığdıramayacağımız kadar seçkin yazılı hitabe örnekleri mevcuttur. Sözlü ve yazılı hitabeler, yüzyıllardan beri nesilden nesile nakledilerek günümüze kadar gelmiştir.

Görülüyor ki, insanlığın sağlıklı ilişki tesisinde hitabet sanatının değeri ve oynadığı rol çok mühimdir. Hitabetin, toplum hayatında iletişim ihtiyacını sağlayan yegâne amillerden biri olduğunu ifade etmek, bu konuda vurgulanacak temel bir noktadır. Her ne kadar teknolojik gelişmeler, baş döndürücü seviyede zirvelere çıksa da, insanların hitabete olan ihtiyacı kesilmeyecek, ilim ve teknoloji sayesinde güçlenerek daha da artacaktır.

\section{Kaynakça}

Ahmet Cevdet Paşa (1980). Kısas-ı Enbiyâ ve Tevârîh-i Hulefâ (sadeleştiren: Ali Arslan), İstanbul: Arslan Yayınları.

Albayrak, N. (2006). "Nasreddin Hoca", DİA, İstanbul: T. D. V. Yayınları, C. XXXII, s. 418-420.

Algül, H. (2002). İlmihal, Ankara: Türkiye Diyanet Vakfı Yayınları.

Âlûsî, M. Ş. (1314/1896). Bulüğu'l-İreb fì Ahvali'l-Arab, Bağdat: y.y.

Atıyye, M. H. (1936). el-Edebu'l-Arabiyyu ve Tarihuhu Fi'l-Asri'l-Cahili, y.y.y.: y.y.

Âyid, A. v.d. (2003). Mu'cemu'l-Arabiyyü'l-Esâsiyyu, Tunus: y.y.

Câhiz, E. U. (1418/1998). el-Beyân ve't-Tebyîn, Kahire: Mektebetü'l-Hanc1.

Cârim, A. ve Emin, M. (2010). el-Belâğatu'l-Vâzıha, Beyrut: Dâru'l-Fikr.

Cevâd, A. (1993). el-Mufassal fi Tarihi'l-Arab Kable'l-İslâm, y.y.y.: y.y.

Cirit, H. (2012). "Vaaz", DIA, İstanbul: T. D. V. Yayınları, C. XLII, s. 407-407.

Çakan, İ.L. 1995. Hitabet ve İşsad Açısından Kur'an-ı Kerim'de Söz Çeşitleri”, I. Din Şurası Tebliğ ve Müzakereleri (1-15 Kasım 1993), c. I, Ankara: DİB Yayınları.

Çakan, İ. (1998). Dinî Hitabet (Çeşitleri-İlkeleri-Örnekleri), İstanbul: İFAV Yayınları.

Çetin, A. (1998). Hitabet ve İrşad Güzel Konuşma ve İnsanları Etkileme Yolları, Bursa: Aksa Yayınları.

Demirayak, K. ve Savran, A. (1993). Arap Edebiyatı Tarihi Câhiliye Dönemi, Erzurum: Atatürk Üniversitesi Fen-Edebiyat Fakültesi Yayını.

Diyanet İşleri Başkanlığı (2015). “Kur’an-1 Kerim”, http://kuran.diyanet.gov.tr/ (Erişim tarihi: 28.05.2015).

Doğru, M. (2000). Hitabet, İstanbul: Damla Yayınevi.

Dozy, R. (1981). Tekmiletu'l-Me'âcimi'l-Arabiyye (çev., Muhammed Selim en-Nu'aymî), Irak: Dâru'r-Reşîd, c. IV, Irak, 1981. 
Durmuş, İ. (2009). "Seci", DIA, İstanbul: T. D. V. Yayınları, C. XXXVI, s. 273-275.

Ekşi, A. (2012). Hitabet ve Mesleki Uygulama Ders Kitabı, y.y.: MEB Yayınları.

Fîrûzâbâdî, M. (2008). el-Kâmûsu'l-Muhît, Kahire: Dâru'l-Hadis.

Göçgün, Ö. (2004). Güzel Konuşma Sanatı (Diksiyon, Hitabet), Ankara: Günce Yayıncılık. Hafâcî, M. (1412/1992). el-Hayatu'l-Edebiyye fi'l-Asri'l-Câhilî, Beyrut: Daru'l-Cîl.

İbn Manzûr, (t.y.). Lisânu'l-Arab, Kahire: Dâru'l-Maârif.

Kaçalin, M.S. (2007). "Orhon Yazıtları", DIAA, İstanbul: T. D. V. Yayınları, C. XXXIII.

Kapar, M.Ali. DIA. (1995). "Eyyâmü'l-Arab", İstanbul: T. D. V. Yayınları, C. XII, s. 14-16.

Kaya, M. (1991). "Aristo", DİA, İstanbul: T. D. V. Yayınları, C. III, s. 375-378.

Kaya, M. (1998). "Hitabet", DİA, İstanbul: T. D. V. Yayınları, C. XVIII, s. 156-158.

Kaya, M. (2002). "Kindî", DIAA, Ankara: T. D. V. Yayınları, C. XXVI, s. 41-58.

Kazanc1, A.L. (1980). Peygamber Efendimiz'in Hitabeti, İstanbul: Marifet Yayınları.

Keskioğlu, O. (2014). Siyer-i Nebi (Hazret-i Peygamberin Hayatı), Ankara: DİA Yayınlan.

Kılıç, H. (1992). "Belâgat”, DİA, İstanbul: T. D. V. Yayınları, C. V, s. 380-383.

Mâcit, İ. (1328/1912). Inşâd ve Hitabet, İstanbul: Resimli Kitap Matbaası.

Mahfûz, A. (t.y.). Fennü'l-Hatâbe, y.y.y.: Dâru'l-İ'tisâm.

Maksudoğlu, M. (2005). Arapça Dilbilgisi, İstanbul: Ensar Neşriyat.

Öngören, R. (2004). "Mevlânâ Celâleddîn-i Rûmî", DİA, Ankara: T. D. V. Yayınları, C. XXIX, s. 441-448.

Özaydın, A. (2001). "Kāim-Biemrillâh", DİA, İstanbul: T. D. V. Yayınları, C. XXIV, s. 210211.

Özön, M.N. (1954). Edebiyat ve Tenkid Sözlüğ̈̈, İstanbul: İnkılâp ve Aka Yayınevi.

Pala, İ. (2000). "İnşâd", DIA, İstanbul: T. D. V. Yayınları, C. XXII, s. 342.

Safvet, A.Z. (1933). Cemheratu Hutabi'l-Arab, Kahire: y.y.y.

Sallâbî, A.M. (2013). Selçuklular, Bâtıni Fitnesine ve Haçlı Savaşına Karşı Bir İslâmî Mücadele Projesinin Doğuşu (çev., Şerafettin Şenaslan, Necmettin Salihoğlu), İstanbul: Ravza Yayınları.

Sami, Ş. (1998). Kâmus-ı Türkî, İstanbul: Alfa Basın-Yayım.

Serinsu, A.N. v.d., (2009). Dinî Terimler Sözlüğü, Ankara: MEB Yayınları.

Sümer, F. ve S. Ali. (1971). İslâm Kaynaklarına Göre Malazgirt Savaşı, Ankara: Türk Tarih Kurumu Yayınları.

Şelbî, A. (1987). Hatâbetu ve I'dêdu'l-Hatîb, Kahire: Dâru'ş-Şurûk.

Şeşen, R. (2012). "Türk", DİA, İstanbul: T. D. V. Yayınları, C. XLI, s. 490-493.

Tatc1, M. (2013). "Yûnus Emre", DİA, İstanbul: T. D. V. Yayınları, C. XLIII, s. 600-606.

Turan, O. (1969). Selçuklular Tarihi ve Türk İslâm Medeniyeti, İstanbul: Turan Neşriyat Yurdu.

Tülücü S. (2005). "Muallakāt”, DİA, İstanbul: T.D.V. Yayınları, C. XXX, s. 310-312. 
Türk Dil Kurumu (2015). “Güncel Türkçe Sözlük”, http://www.tdk.gov.tr / (Erişim tarihi: 29.05.2015).

Türk Dil Kurumu (2017). "Güncel Türkçe Sözlük”, http://www.tdk.gov.tr / (Erişim tarihi: 21.07.2017).

Türk Dil Kurumu (2017). "Güncel Türkçe Sözlük”, http://www.tdk.gov.tr / (Erişim tarihi: 23.07.2017).

Uğur, Mücteba, (1986). Va’z, K1ssac1lık ve Hadiste Kussâs, Ankara Üniversitesi İlahiyat Fakültesi Dergisi, 28/291-326.

Uralgiray, Y. (1986). Illk ve Illeri Dilbilgisi, Riyâd: y.y.y.

Uzun, M. (1998). "Hitabet", DİA, İstanbul: T. D. V. Yayınları, C. XVIII, s. 160-163.

Uzun, M. (2000). Türk Hitabet Tarihine Genel Bir Bakış, Marmara Üniversitesi Illahiyat Fakültesi Dergisi, 19 / 145-169.

Yavuz, Y.Ş. (2006). "Münâzara", DİA, İstanbul: T. D. V. Yayınları, C. XXXI, s. 576-577.

Yeğin, A. (2008). Yeni lügat, İstanbul 2008: Hizmet Vakfi Yayınları.

Zeyyât, A.H. (t.y.). Târîhu'l-Edebi'l-Arabî, Kahire: Dâru Nehdat Masr.

\section{EK-1. İSLAM ÖNCESİ CAHILIYE DEVRİ ARAP HITABESİ ÖRNEĞİ}

Kus b. Sâide el-İyâdî’nin Ukâz Çarşısında İrad Ettiği Meşhur Hitabesi

Kus b. Sâide, Câhiliye döneminde çok yaşlı olduğu sıralarda, Ukâz panayırında kızıl bir deve üzerinde, meşhur Arap şairleri ve hatiplerinin hazır bulunduğu esnada bir hutbe irad etmiştir. O zaman Hz. Muhammed (s.a.v.)'de genç yaşlarında Sûk-1 Ukâz'da bu hitabeyi dinlemiş (Keskioğlu, 2014: 29) ancak henüz insanları İslâm dini'ne davet ile görevlendirilmemişti. Kus'un bu konuşması, Arap edipleri arasında çok fazla şöhret bulmuş ve dillerde destan olmuştur. (Ahmet Cevdet Paşa, 1980: I, 52) Hitabenin metni şöyledir:"Ey insanlar! Dinleyiniz, (söylediklerimi) aklınızda tutup belleyiniz. Hayat süren ölür ve fena bulur, her gelen (istikbalde) olacak olur. Gece kapkaranlıktır, gelip giden gündüz, burçlarla dolu gökyüzü ve yıldızlar 1şıldayıp parlar, denizler yükselir, dağlar (gemi demiri gibi) sabittir, arz (yeryüzü) silindir gibi düzdür ve nehirler akar. Şüphesiz, gökte haber, yerde ders / ibret alınacak çok mühim şeyler vardır, (acaba) insanlara ne oluyor ki giderler ve geriye dönmezler? Acaba (onlar) razı olup ta mı (ikamet ediyor) kalıyorlar? Yoksa (orada) bırakılıp (terk edilip) uykuya mı dalıyorlar?

Ey İyâd topluluğu, (hani) nerede babalarınız, ecdadınız (atalarınız), nerede şiddetli / o zorba firavunlar? Onlar size göre malca daha zengin ve ecelleri bakımından sizden daha uzun olmadılar mıydı (öyle değiller mi)? Dehr (geçen uzun zaman), onları (değirmeninde) ezip un gibi öğüttü, kibirleriyle birlikte paramparça etti. (Zeyyât, t.y.: 21; Safvet, y.y.: 1933, I, 35-36; Atıyye, 1936: 75-76)

Önce geçen toplumlarda bizim için ibretler var.

Ölümü açıklayan kaynaklar görmedim, buna işaret eden yollar da yoktur. 
Kavmimi büyüğüyle küçü̆̆̈̈yle ölüme doğru giden kaynaklarda gördüm.

Gidenler bana geri dönmüyor, bana mazi, geri gelmiyor ve kalanlar da süreklilik göstermiyorlar (mazide durmuyor),

Kesin (emin) oldum ki, kavmim nerdeyse ben de öyle olacağım / oraya gideceğim. (Zeyyât, t.y.: 21; Atıyye, 1936: 75-76)

\section{EK-2. SELÇUKLU DÖNEMİ İSLAMİ TÜRK HITTABESİ ÖRNEĞİ}

Alparslan ve Malazgirt Zaferi (h.463/m.1071)

Selçuklu devletiyle Bizans arasında icra edilen Malazgirt Savaşı henüz başlamadan, Abbâsî Halifesi el-Kâim-Biemrillâh ${ }^{7}$ (ö. 467/1075), hatiplerin minberde Alparslan ve İslâm ordusunun zaferi için dualar etmelerini emretmiş ve ayrıca dua metni hazırlatarak bütün camilerde okumaları amacıyla hatiplere göndermiştir. Dua metni kısaca şöyledir: (Sümer ve Sevim, 1971: 7) “Allah'ım! İslâm'ın sancaklarını yükselt ve hayatlarını sana kulluk için esirgemeyen mücahitlerini yalnız bırakma; Alparslan'1 düşmanlarına muzaffer kıl ve askerlerini meleklerin ile teyit eyle; zira o, senin rızanı kazanmak için varını, canını ve her şeyini fedadan sakınmıyor; o, senin yolunda ve dininin üstünlügü için nasıl cihad ediyor ise sen de onu öylece koru; düşmanlarını kahret!

Ey Müslümanlar, temiz bir kalp ile sultana dua ediniz; küfrün kökünü kazımak ve İslâm'ın bayraklarını yüceltmek için yalvarınız." (Turan, 1969: 138). Sultanın imam ve fakihi (Sümer ve Sevim, 1971: 52) Ebu Nasr Muhammed b. Abdulmelik el-Buhari el-Hanefi, Sultan Alparslan'a şöyle demiştir: (Sallâbî, 2013: 96)

“Ey Sultan! Sen Allah'ın başka dinlere zafer vaad eylediği İslâmîyet uğrunda cihad yapıyorsun; bütün Müslümanlar minberlerde sana dua yaptığı Cuma günü savaşa giriş. (Turan, 1969: 137) Umuyorum ki Allah (c.c.) bu fethi kaderde sana yazmıştır.” (Sallâbî, 2013: 96)

Cuma gününe kadar henüz ciddi bir çarpışma gerçekleşmemişti. (Turan, 1969: 138) Sultan, hatiplerin Cuma saatinde minberde hutbe okuyacağı zamanı bekliyordu. (Sümer ve Sevim, 1971: 8) Namaz vakti girdiğinde sultan, askerlerle namaz kılıp Allah'a dua ederek ağlamıştı. (Sallâbî, 2013: 96) Cuma namazını müteakip Sultan Alparslan ordu kumandanlarını, (Sümer ve Sevim, 1971: 57) beylerini ve askerlerini toplayarak onlara şöyle hitap etmiş̧ir: (Turan, 1969: 138). "Biz bu kalabalığın karşısında azın da altındayız. Sizden kim peşimden gelmek istiyorsa gelsin. Kim de gitmek istiyorsa gitsin. Burada ne emreden bir sultan, ne de emredilen bir asker vardır. Burada Allah'dan başka bir sultan yoktur; emir ve kader tamamiyla onun elindedir." Ben bugün ancak sizden biriyim, sizinle savaşan bir askerim. Kim bana uyar ve canını Allah için feda ederse ona cennet veya ganimet vardır. Kim çekip giderse ona da cehennem ve zillet vardır." Askerler de buna karşılık "Asla emrinden ayrılmayacağız" diye cevap verdi. (Turan, 1969: 138; Sallâbî, 2013: 96) Sultan, bu konuşmasının ardından ölüm için hazırlığı ifade eden ve kendisine kefen olacak beyaz elbiseyi giydi ve ordusuna: "bu kefenimdir" dedi. İki taraf arasında cenk/çarpışma

\footnotetext{
${ }^{7}$ Ebû Ca‘fer el-Kāim-Biemrillâh Abdullāh b. Ahmed el-Kādir-Billâh el-Abbâsî (ö. 467/1075) Abbâsî halifesi (1031-1075) tarihlerinde halifelik yapmıștır (Abdülkerim Özaydın, "Kāim-Biemrillâh”, DİA, İstanbul 2001, c. 24, s. 210-211).
} 
başladığında Alparslan yüzünü toprağa sürüp tevazu ile ağlayarak (Sallâbî, 2013: 96) Allah’a secde ile şöyle dua ediyordu: "Eğer içim dişıma uygun geliyorsa düşmanlara karşı cihadımda bana yardım et ve beni muzaffer bir sultan k1l."

İki taraf Cuma günü hatiplerin minberde bulunduğu vakit karşılaştı. İslâm orduları, Malazgirt zaferini kazandığında Halife el-Kâim-Biemrillâh, Sultan Alparslan'a bir mektup göndererek onu kazandığı zaferden dolayı tebrik ederek kutlamıştı. (Sümer ve Sevim, 1971: $9,11)$. 